\title{
Pengaruh Model Pembelajaran Kooperatif Tipe Talking Stick Berbantuan Media Animasi Flash terhadap Hasil Belajar Fisika Siswa Kelas X SMA Katolik Palu
}

\author{
Oktovianus Sario Sucipto, Syamsu, dan Darsikin \\ Riosucipto016@gmail.com \\ Program Studi Pend. Fisika, Jurusan Pendidikan MIPA, Universitas Tadulako \\ Jl. Soekarno Hatta KM. 9 Kampus Bumi Tadulako Tondo Palu - Sulawesi Tengah
}

\begin{abstract}
Abstrak - Penelitian ini bertujuan untuk mengetahui pengaruh model pembelajaran kooperatif tipe talking stick berbantuan media animasi flash terhadap hasil belajar fisika siswa kelas X di SMA Katolik Palu. Jenis penelitian ini merupakan eksperimen kuasi dengan desain pretest-posttest control group design. Populasi penelitian ini adalah seluruh siswa kelas X SMA Katolik Palu. Teknik sampling yang digunakan dalam penelitian ini adalah proposive sampling dengan sampel penelitian adalah kelas X MIA 2 sebagai kelas eksperimen dan kelas X MIA 1 sebagai kelas kontrol. Instrumen hasil belajar fisika berupa tes pilihan ganda yang telah divalidkan melalui validitas kontruksi. Tes hasil belajar fisika yang diperoleh menunjukkan bahwa skor rata-rata kelas eksperimen 12,62 lebih tinggi dari pada kelas kontrol yaitu 10,74 dari skor ideal yaitu 21 . Uji hipotesis Uji-t (dua pihak), diperoleh $t_{\text {hitung }}=2,25$ dan $t_{0,975(48)}=2,01$ pada taraf nyata $a=0,05$. Ini berarti bahwa nilai $t_{\text {hitung }}$ berada diluar daerah penerimaan $\mathrm{H}_{0}$. Hasil menunjukkan bahwa ada pengaruh model pembelajaran kooperatif tipe talking stick berbantuan media animasi flash terhadap hasil belajar fisika siswa kelas X SMA Katolik Palu.
\end{abstract}

Kata Kunci: model pembelajaran kooperatif tipe talking stick, media animasi flash, hasil belajar

\section{PENDAHULUAN}

Pendidikan merupakan salah satu faktor yang menentukan tingkat kemajuan suatu negara terutama bagi negara-negara yang sedang berkembang guna mengejar ketinggalanya dalam bidang ilmu pengetahuan dan teknologi. Bangsa Indonesia yang juga merupakan salah satu negara yang sedang berkembang, perlu adanya peningkatan mutu pendidikan untuk mencapai kemajuan di segala bidang. Untuk menciptakan suatu masyarakat yang maju maka harus dilakukan usaha-usaha yang dapat meningkatkan mutu pendidikan disemua jenjang pendidikan tersebut. Mutu pendidikan dikatakan baik jika proses belajar mengajar disemua jenjang tersebut benar-benar efektif dan efesien sehingga siswa dapat mencapai kemampuan intelektual, sikap, dan keterampilan yang diharapkan.

Salah satu pemasalahan yang sering dihadapi dunia pendidikan adalah rendahnya hasil belajar siswa. Hal tersebut disebabkan karena tenaga pengajar kurang bervariasi dalam menentukan proses pembelajarannya shingga siswa merasa bosan.

Proses pembelajaran dipengaruhi dua faktor yaitu faktor internal dan faktor eksternal. Faktor internal adalah faktor yang berasal dari dalam diri guru dan siswa seperti rasa malas, bosan dan gembira. Sedangkan faktor eksternal adalah faktor yang berasal dari guru dan siswa seperti lingkungan sekolah, ruang belajar, model pembelajaran berlangsung, guru harus pandai memilih penggunaan model pembelajaran yang tepat [1].

Guru perlu memilih model pembelajaran yang cocok untuk model pembelajaran yang diterapkan menurut caranya sendiri. Model pembelajaran terpadu pada hakikatnya merupakan suatu model pembelajaran yang memungkinkan siswa baik secara individual maupun kelompok aktif mencari, menggali, dan menemukan konsep serta prinsip-prinsip secara holistik dan autentik [2].

Model pembelajaran yang baik diharapkan dapat meningkatkan kualitas proses pembelajaran dikelas dan dapat meningkatkan penguasaan materi tersebut. Maka diperlukan suatu inovasi penggunaan model pembelajaran yang sesuai yaitu model pembelajaran talking stick. Salah satu keunggulan model pembelajaran ini adalah melatih siswa untuk berbicara, pembelajaran ini akan menciptakan suasana belajar yang menyenangkan dan membuat siswa aktif dalam pembelajaran serta meningkatkan kesiapan siswa dalam memecakan masalah yang di berikan oleh guru [3].

Berdasarkan penelitian Gintoe yang dilakukan pada tahun 2015 dapat diketahui bahwa penggunaan model pembelajaran talking stick meningkatkan hasil belajar siswa. Peneltian model pembelajaran kooperatif tipe talking stick sangat jarang dilakukan dalam pembelajaran fisika. Oleh karena itu, dengan model 
pembelajaran talking stick diharapkan dapat meningkatkan hasil belajar siswa [4].

Tidak hanya itu, model pembelajaran juga perlu adanya bantuan media pembelajaran, sehingga dalam proses pembelajaran dapat membangkitkan keinginan dan minat yang baru, membangkitkan motivasi dan rangsangan kegiatan belajar dan bahkan membawa pengaruh psikologis terhadap siswa.

$\mathrm{Hal}$ ini sejalan dengan yang diungkapkan Kinaseh pada penelitiannya yang dilakukan pada tahun 2015 bahwa media pembelajaran animasi dapat menunjang proses belajar yang menyenangkan dan menarik bagi siswa dan juga memperkuat motivasi dan juga untuk menanamkan pemahaman pada siswa tentang materi yang diajarkan [5].

Tujuan menggunakan media pebelajaran yaitu untuk mempertinggi mutu megajar dan belajar. Di samping itu media pembelajaran mempunyai fungsi yaitu memperjelas penyajian pesan dan informasi sehingga dapat memperlancar dan meningkatkan proses dan hasil belajar [6]. Selain itu pemilihan media pembelajaran yang tepat akan menimbulkan semangat, gairah, dan mencegah kebosanan siswa untuk belajar.

Berdasarkan uraian diatas, terdapat beberapa permasalahan yang diidentifikasi yaitu kurang terampilnya guru dalam menentukan metode yang tepat dalam proses belajar mengajar, dan penerapan metode pembelajaran yang kurang bervariasi sehingga hasil dan motivasi siswa dalam belajar rendah.

Berdasarkan uraian diatas, peneliti bermaksud untuk melakukan penelitian tentang pengaruh model pembelajaran kooperatif tipe talking stick berbantuan media animasi flash terhadap hasil belajar fisika siswa kelas X SMA Katolik Palu.

\section{METODE PENELITIAN}

Sampel diambil dengan pertimbangan tertentu dari guru mata pelajaran fisika pada kedua kelas di sekolah tersebut. Kedua kelas yang dipilih merupakan kelas yang dianggap homogen secara akademik.

Adapun desain penelitian yang digunakan adalah pretest-posttest group design. Desain ini digunakan untuk kelompok yang telah ada sebelumnya dan pengambilan kelompoknya dilakukan secara acak (random) [7]. Desain penelitian yang digunakan seperti pada Tabel 1 .
TABEL 1 DESAIN PENELITIAN

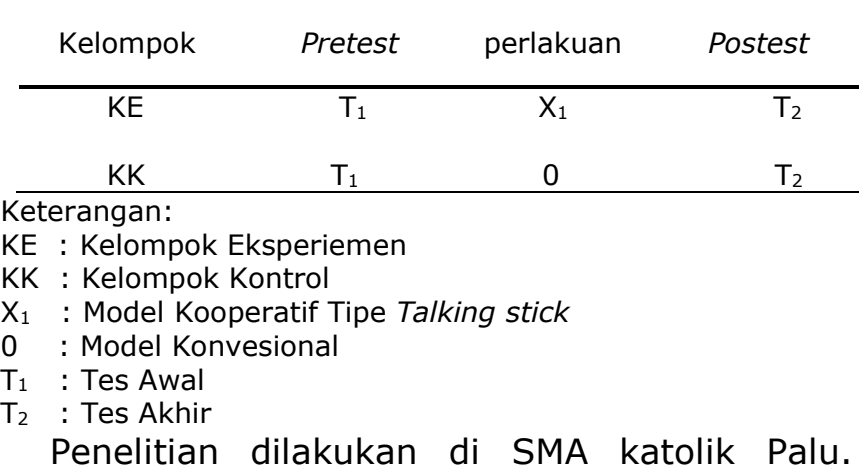
Populasi dalam penelitian ini adalah seluruh siswa kelas X MIA di SMA Katolik Palu tahun pelajaran 2017/2018 yang terdiri dari 2 kelas. Sampel dalam penelitian ini adalah kelas X MIA 1 yang berjumlah 25 siswa dan X MIA 2 yang berjumlah 25 siswa. Teknik pengumpulan sampel yang digunakan adalah purposive sampling, yaitu teknik penentuan sampel dengan pertimbangan sistem penempatan siswa di dalam kelas serta waktu belajar yang sama.

Instrumen yang digunakan dalam penelitian ini adalah tes pilihan ganda berjumlah 21 soal, untuk melihat hasil belajar siswa pada mata pelajaran fisika yang telah divalidasi oleh validator ahli. Analisis data dilakukan dengan menganalisis data hasil penelitian menggunakan uji statistik $t$ dua pihak.

\section{HASIL DAN PEMBAHASAN}

\section{A. Hasil Penelitian}

Skor rata-rata pretest kelas eksperimen sebesar 8,86 dengan standar deviasi sebesar 2,43 . Sedangkan untuk kelas kontrol, skor rataratanya sebesar 8,46 dan standar deviasi sebesar 3,06 dari skor idela yaitu 21 . Selanjutnya pada posttest, skor rata-rata kelas eksperimen sebesar 12,62 dengan standar deviasi 3,00 dan untuk kelas kontrol skor rataratanya sebesar 10,57 dengan standar deviasi sebesar 2,96 dari skor ideal yaitu 21. Adapun data hasil penelitian di atas, disajikan pada Tabel 2.

TABEL 2 DESKRIPSI SKOR TES HASIL BELAJAR FISIKA SISWA UNTUK KELAS

\begin{tabular}{lcccc} 
& \multicolumn{2}{c}{ EKSPERIMEN DAN KELAS KONTROL } & \multicolumn{2}{c}{ Posttest } \\
\cline { 2 - 5 } Uraian & $\begin{array}{c}\text { Pketest } \\
\text { men }\end{array}$ & Kontrol & $\begin{array}{c}\text { Eksperi } \\
\text {-men }\end{array}$ & $\begin{array}{c}\text { Kontr } \\
\text { ol }\end{array}$ \\
\hline Sampel $(\mathrm{n})$ & 25 & 25 & 25 & 25 \\
Nilai maksimum & 14 & 14 & 18 & 17 \\
Nilai minimum & 3 & 3 & 7 & 6 \\
Skor rata-rata & 8,86 & 8,46 & 12,62 & 10,74 \\
Standar deviasi & 2,43 & 3,06 & 3,00 & 2,96 \\
\hline
\end{tabular}


Uji normalitas data digunakan untuk mengetahui apakah populasi data berdistribusi normal atau tidak. Data yang diuji normalitas adalah data hasil Pretest pada kelas eksperimen dan kelas kontrol. Pengujian normalitas data pretest pada penelitian menggunakan uji Chikuadrat dengan kriteria penerimaan $\chi^{2}$ hitung $<$ $\chi^{2}$ tabel, taraf signifikan $\alpha=0,05$, dan derajat kebebasan $\mathrm{dk}=\mathrm{k}-3$. Dari Tabel 3 terlihat bahwa nilai $\chi^{2}$ hitung kelas eksperimen maupun kelas kontrol lebih kecil daripada nilai $\chi^{2}$ tabel. Hasil ini menunjukan bahwa data pretest kelas eksperimen maupun kelas kontrol terdistribusi normal (Tabel 3).

TABEL 3. NORMALITAS DISTRIBUSI TES AWAL DAN TES AKHIR PADA KELAS EKSPERIMEN DAN KELAS KONTROL

$$
\text { Eksperimen Kontrol }
$$

\begin{tabular}{lcccc} 
Uraian & Tes Awal & Test Akhir & Tes Awal Tes Akhir \\
\cline { 2 - 5 } & & & & \\
\hline Sampel & 25 & 25 & 25 & 25 \\
$\chi^{2}$ hitung & 1,69 & 4,53 & 2,83 & 5,58 \\
$\chi^{2}$ tabel & 7,81 & 7,81 & 7,81 & 7,81 \\
\hline
\end{tabular}

Uji homogenitas pada penelitian ini menggunakan uji statistik $\mathrm{F}$ dengan taraf signifikansi $a=0,05$. Berdasarkan hasil output uji homogenitas pada Tabel 4 dengan taraf signifikansi $(a=0,05)$, dari data tersebut terlihat bahwa Fhitung lebih kecil dari $F_{\text {tabel, }}$ maka berdasarkan kriteria pengambilan keputusan dapat disimpulkan bahwa tidak terdapat perbedaan varians antara kelas eksperimen dan kelas kontrol atau dengan kata lain varians antara kelas eksperimen dan kelas kontrol adalah sama atau homogen. Setelah terpenuhinya uji normalitas dan homogenitas, maka dilakukan uji beda rata-rata (dua pihak) atau uji-t. Uji-t tersebut diperoleh berdasarkan data pretest dan data posttest. hasil dapat dilihat pada Tabel 5 dan Tabel 6 .

TABEL 5 UJI BEDA RATA-RATA (DUA PIHAK) PRETEST KELAS EKPERIMEN DAN KELAS KONTROL

Kelas Nilai rata-rata $t$ hitung $t$ table $(a=0,05)$ Keputusan

$\begin{array}{lcccc}\begin{array}{l}\text { Ekspe- } \\ \text { rimen } \\ \text { Kontrol }\end{array} & 8,86 & \begin{array}{c}0,51 \\ \text { diterima }\end{array} & 2,01 & \mathrm{H}_{0} \\ \end{array}$

Berdasarkan data Tabel 5 dan kriteria pengujian dimana $H_{0}$ diterima jika $t_{\left(1-\frac{1}{2} \alpha\right)}<t<$ $t_{\left(1-\frac{1}{2} \alpha\right)}$ pada taraf signifikansi $\alpha=0,05 \mathrm{dan} \mathrm{dk}=$ 48 , diperoleh $t_{0,05(48)}=2,01$ dan $t_{\text {hitung }}=0,51$. Hal ini menunjukkan bahwa nilai $t_{\text {hitung }}$ berada pada daerah penerimaan $H_{0}$. Dapat dikatakan bahwa tidak terdapat perbedaan hasil belajar peserta didik kelas X MIA 2 dan X MIA 1.

TABEL 6 UJI BEDA RATA-RATA (DUA PIHAK) POSTTEST KELAS EKPERIMEN DAN KELAS KONTROL

Kelas Nilai rata-rata $\mathrm{t}_{\text {hitung }} \mathrm{t}_{\text {table }}(\mathrm{a}=0,05)$ Keputusan

Ekspe- 12,62

rimen

$2,25 \quad 2,01$

$\mathrm{H}_{1}$ diterima

Kontrol 10,74

Berdasarkan data Tabel 6 diketahui $\mathrm{t}_{\text {hitung }_{(2,25)}}>$ $t_{\text {tabel }_{(2,01)}}$ atau $\mathrm{t}_{\text {hitung }}$ (-2,25) $<\mathrm{t}_{\text {tabel }_{(-2,01)}}$. Hal ini berarti, nilai thitung berada di luar daerah penerimaan $\mathrm{H}_{0}$. Dengan demikian $\mathrm{H}_{0}$ ditolak dan $\mathrm{H}_{1}$ diterima, dan dapat disimpulkan bahwa ada pengaruh pembelajaran kooperatif tipe talking stick berbantuan media animasi flash terhadap hasil belajar fisika siswa kelas X SMA Katolik Palu. Dengan kata lain, nilai hasi belajar kelas eksperimen lebih tinggi dibanding dengan kelas kontrol.

\section{B. Pembahasan}

Penelitian ini bertujuan untuk mengetahui ada tidaknya pengaruh model pembelajaran kooperatif tipe talking stick terhadap hasil belajar siswa pada kelas eksperimen. Penelitian ini dilakukan pada kelas X MIA 2 sebagai kelas eksperimen dan kelas $X$ MIA 1 sebagai kelas kontrol dengan melalui beberapa pertimbangan, diantaranya guru mata pelajaran yang sama, jumlah waktu pembelajaran yang sama yaitu selama 3 jam pelajaran dengan 1 kali pertemuan, tingkat kemapuan siswa yang hampir sama, serta pokok bahasan yang disampaikan pada kelas eksperimen dan kelas kontrol juga sama yaitu gerak lurus.

Sebelum melaksanakan proses pembelajaran di kedua kelas tersebut, terlebih dahulu dilakukan tes awal (pretest) dalam bentuk soal pilihan ganda dengan jumlah soal sebanyak 21 butir soal. Sebelum diberikan kepada kelas kontrol dan kelas eksperimen soal yang digunakan ini telah diuji cobakan pada siswa yang telah melewati materi gerak lurus yaitu pada kelas XI IPA 1 SMA Katolik Palu dan telah terbukti memenuhi syarat untuk digunakan sebagai tes standar. Pemberian tes awal kepada kedua kelas yang menjadi sampel penelitian dilakukan dengan tujuan untuk mengetahui pengetahuan awal siswa mengenai materi gerak lurus yang kemudian akan dibandingkan dengan hasil tes akhir (posttest) dengan bentuk soal dan jumlah soal yang sama.

Pelaksanaan penelitian pada kegiatan inti di kelas eksperimen dilakukan oleh peneliti dengan fase-fase sebagai berikut, menjelaskan 
mengenai teknik pelaksanaan model pembelajaran kooperatif tipe talking stick. Selanjutnya, peneliti meminta siswa untuk membentuk kelompok yang terdiri dari 4-5 kelompok di setiap pertemuan. Peneliti membagikan LKPD kepada masing-masing kelompok kemudian setiap masing-masing kelompok mengerjakan LKPD. Setelah selesai mengerjakan LKPD, masing-masing perwakilan kelompok mempresentasikan hasil kerjanya kepada kelompok lain mengenai materi gerak lurus. Setelah itu peneliti memberikan minimal 5 atau 10 menit untuk belajar kepada masingmasing kelompok tentang materi tersebut. setelah kelompok selesai mempelajari materi tersebut, guru mempersilahkan anggota kelompok untuk menutup isi bacaan. Peneliti mengambil tongkat atau stick dan memberikan kepada kelompok yang mendapatkan paket pertanyaan pertama, setelah itu memberikan pertanyaan dan anggota kelompok yang memegang tongkat tersebut harus menjawabnya, demikian seterusnya sampai semua kelompok mendapat pertanyaan. Kemudian peneliti membahas pertanyaan sebagai penguat pemahaman siswa.

Proses pembelajaran yang berlangsung di kelas kontrol menggunakan model pembelajaran konvensional yang sering digunakan di SMA Katolik Palu. Pelaksanaan fase-fase pembelajaran pada kegiatan inti di kelas kontrol dimulai dengan menjelaskan secara keseluruhan mengenai materi gerak lurus kepada siswa kemudian memberikan kepada siswa untuk bertanya mengenai penjelasan yang diberikan ataupun peneliti bertanya kepada siswa dan memberikan kesempatan kepada siswa untuk menjawab pertanyaan yang diberikan. Selanjutnya, peneliti memberikan contoh soal mengeni materi pembahasan kepada siswa lalu meminta siswa untuk memerhatikan contoh soal agar siswa dapat mengerjakan latihan soal yang guru berikan selanjutnya. Setelah itu, peneliti membentuk 4 atau 5 kelompok. Kemudian setiap masing-masing kelompok mengerjakan LDS yang diberikan peneliti. Setelah selesai mengerjakan LDS, masing-masing perwakilan kelompok diminta untuk maju didepan kelas untuk mengerjakan LDS agar teman-teman siswa yang lain memerhatikan pekerjaan tersebut dan diperbolehkan untuk menanggapi jawaban pekerjaan temannya, kemudian guru menyimpulkan dan meluruskan jawaban siswa. Sebelum kelas ditutup guru memberikan kesempatan kembali pada siswa untuk bertanya jika masih ada penjelasan yang kurang dipahami mengenai materi secara keseluruhan.
Berdasarkan analisis kuantitatif, kemampuan awal siswa dengan memberikan tes awal diketahui skor rata-rata untuk kelas eksperimen 8.86 dan untuk kelas kontrol 8.46. Hal ini menunjukkan kemampuan akademik siswa sebelum diberikan perlakuan dianggap sama sebelum diberi perlakuan. Dan setelah diberi perlakuan, kemampuan akhir siswa dengan memberikan posttest diketahui skor rata-rata untuk kelas eksperimen sebesar 12.62 dan untuk kelas kontrol 10.74. Hasil ini menunjukkan adanya perbedaan skor antara dua kelas, dimana skor rata-tara kelas eksperimen lebih tinggi dibandingkan kelas kontrol, hasil pemberian posttest ini didukung oleh hasil analisis uji hipotesis (Uji-t) dua pihak. Dimana dari perhitungan diperoleh nilai $t_{\text {hitung }}=2.25$ dan $t_{\text {tabel }}=2.01$. Berdasarkan hasil tersebut diketahui nilai $t_{\text {hitung }} \geq t_{\text {tabel }}$ atau $2.25 \geq 2.01$, yang artinya hipotesis $\mathrm{H}_{0}$ ditolak. Dengan kata lain ada pengaruh hasil belajar fisika siswa yang menggunakan model pembelajaran kooperatif tipe talking stick dengan hasil belajar fisika siswa yang menggunakan model pembelajaran konvensional pada siswa SMA Katolik Palu.

Setelah dilakukan pembuktian antara dua variabel dengan menggunakan uji-t dapat diketahui bahwa pengujian hipotesis peneliti ini terdapat pengaruh yang cukup signifikan antara kelas yang menggunakan model pembelajaran talking stick dengan kelas yang menggunakan model pembelajaran konvesional. Model pembelajaran talking stick ini dapat berpengaruh terhadap hasil belajar siswa dikarenakan pada model pembelajaran ini proses pembelajarannya tidak berlangsung satu arah sehingga siswa tidak hanya terfokus oleh penjelasan guru.

Berbeda kelas kontrol, siswa dalam kegiatan pembelajaran konvesional ini lebih banyak berpikir sendiri dan kurang aktif dalam kegiatan pembelajaran. Hal ini juga dapat mempengaruhi hasil belajar fisika siswa karena tidak secara aktif dan kreatif dalam proses pembelajaran yang seharusnya siswa lebih banyak berperan.

Pernyataan ini juga di dukung oleh penelitianpenelitian sebelumnya. Gintoe dengan penelitiannya pada tahun 2015 menyebabankan hasil belajar siswa yang menggunakan kooperatif tipe talking stick lebih baik dibandingkan siswa yang mengikuti pembelajaran konvesional.

Selain itu penelitian yang dilakukan oleh Samiasih pada tahun 2015 hasil belajar siswa yang menggunakan kooperatif tipe talking stick berbantuan video pembelajaran lebih baik dibandingkan siswa yang mengikuti pembelajaran [8].

Adapun kelebihan model pembelajaran kooperatif tipe talking stick diantaranya menguji 
kesiapan siswa, melatih membaca dan memahami dengan cepat, dan membuat siswa agar lebih giat belajar. Selain dari kelebihan tersebut, adapun kekurangan dari model pembelajaran ini yaitu membuat siswa yang tidak siap dan gugup ketika mendapat bagian tongkat dan menjawab pertanyaan dari guru, kemudian jika siswa tidak memahami, siswa tidak biasa menjawab pertanyaaan, dan waktu yang digunakan cukup lama.Kelebihan model pembelajaran kooperatif tipe talking stick ini di bandingkan dengan pembelajaran langsung adalah keaktifan siswa.

Melalui model pembelajaran kooperatif tipe talking stick ini dapat melatih siswa untuk berani mengungkapkan pendapat tentang topik yang telah didiskusikan bersama teman sekelompok, model pembelajaran ini juga dapat meningkatkan motivasi belajar siswa karena model pembelajarannya yang menarik dan menggunakan tongkat sehingga dapat membuat peserta didik menjadi bersemangat mengikuti kegiatan pembelajaran.

Di samping itu juga dengan adanya berbantuan media animasi flash siswa menjadi tertarik untuk memahami mata pelajaran yang sedang diajarkan. Dari ketertarikan ini diharapkan media juga membangkitkan motivasi belajar siswa, sehingga siswa dapat mengerti atau memahami suatu pelajaran dengan mudah dalam proses belajar mengajar.

\section{KESIMPULAN DAN SARAN}

\section{A. Kesimpulan}

Berdasarkan hasil analisis data yang dilakukan, maka dapat disimpulkan bahwa ada pengaruh model pembelajaran kooperatif tipe talking stick dengan berbantuan media animasi flash terhadap hasil belajar fisika siswa. Hal ini dilihat dari hasil analisis data statistik menggunakan Uji-t dua pihak sampel independent diperoleh nilai $t_{\text {hitung }}>t_{\text {tabel }}$ atau $2.25>2,01$ pada taraf signifikan $\alpha=0,05$ dan derajat kebebasan, $\mathrm{dk}=48$ sehingga hipotesis dapat diterima.

\section{B. Saran}

Berdasarkan hasil penelitian yang telah diperoleh selama melakukan proses pembelajaran, maka penulis menyarankan : (1) Kepada guru bidang studi fisika agar dapat menerapkan model pembelajaran kooperatif tipe talking stick dengan berbantuan media animasi flash pada materi-materi fisika untuk meningkatkan hasil belajar fisika. (2) Bagi sekolah, model pembelajaran kooperatif tipe talking stick ini agar dapat dijadikan alternatif pembelajaran di sekolah untuk mata pelajaran lainnya.

\section{DAFTAR PUSTAKA}

[1] Slameto. Belajar dan faktor-faktor yang mempengaruhinya. Jakarta:Rineka Cipta, 2010.

[2] Departemen Pendidikan dan Kebudayaan, Pengelohan kelas di sekolah dasar. Jakarta:Depdikbud, 1996.

[3] Noryana, "Meningkatkan Minat Belajar PKN Materi Hak Asasi Manusia Menggunakan Model Pembelajaran Talking Stick Pada Siswa Kelas X.A SMA Negeri 11 Banjarmasin", Jurnal Pendidikan Kewarganegaraan. 3(5), 2013.

[4] K.Y Gintoe., Y. Kendek., dan A. Hatibe. "Pengaruh Model Pembelajaran Kooperatif Tipe Talking Stick Terhadap Hasil Belajar IPA Fisika Pada Siswa Kelas VII SMP Negeri 9 Palu", Jurnal Pendidikan Fisika Tadulako (JPFT), 3(4).1-12 2338-3240, 2015.

[5] Kinaseh, Subekti. N, Pribadi. A. T, "Pengaruh Model Problem Based Learning Dengan Media Animasi Flash Terhadap Hasil Belajar Dan Aktivitas Siswa", Unnes journal of biology education, 4(3), 317-321, 2015.

[6] A. Arsyad. Media Pembelajaran. Jakarta:PT Grafindo, 2011.

[7] Sugiyono. Metode Penelitian Kuantitatif Kualitatif dan $R$ \& D. Bandung:Alfabeta, 2008.

[8] A. P. N. Samiasih., M. I. Tegeh., dan K. I. Sudarma. "Pengaruh Model Pembelajaran Talking Stick Berbantuan Video Pembelajaran Terhadap Hasil Belajar Bahasa Indonesia Kelas VIII", E-journal Edutech Universitas Ganesha Jurusan Teknologi Pendidikan, 3(1), 2015. 